\title{
Incarnations of Paul Celan's Todesfuge in the Paintings of Anselm Kiefer and Daniel Libeskind's Jewish Museum, Berlin
}

\author{
Stephen Alexander Wischer \\ Assistant Professor of Architecture, North Dakota State University, Fargo, ND, 58103, USA. \\ Ph.D., Candidate, History and Theory of Architecture, McGill University, Montreal, Quebec, H3A 2T5, Canada.
}

Tel: 701.388.1585, E-mail: stephen.a.wischer@ndsu.edu

doi:10.5618/arch.2012.v1.n2.1 || Received: 17-05-2012, Accepted: 27-05-2012, Available online: 7-06-2012

\begin{abstract}
This paper explores connections between poetry, art and architecture, which emerge across works by the poet Paul Celan, the German artist Anselm Kiefer and architect Daniel Libeskind, in order to foreground the ways in which our creations may bridge written language and speech, touch and space. Transformations of Celan's poem Todesfuge into the paintings Nuremburg and Sulamith by Anselm Kiefer and the architectural spaces of Daniel Libeskind's Jewish Museum, Berlin, not only ensure the life of the poem through translation but demonstrate how historical quotations emerge across varying material combinations and space. In particular, this paper explores how metonymic fragments and the interplay between presence and absence inherent to Celan's poetics appear in the multivalent imagery and use of paint, straw and ash in Kiefer's paintings, as well as in the interstitial "spatial voids" of Libeskind's Museum. Understanding these connections demonstrates the critical potential of our artefacts: art, architecture, written and spoken language, to fluctuate between what is spoken and unsaid, what is seen and left unseen, between the visible and invisible.
\end{abstract}

Keywords: Art; Architecture; Kiefer, Anselm; Celan, Paul; Libeskind, Daniel; Poetics; Hermeneutics

\section{Introduction}

The poem Todesfuge by Paul Celan, the paintings Nuremburg and Sulamith by Anselm Kiefer, and the architectural spaces of Daniel Libeskind's Jewish Museum, Berlin, each cut across conventional art historical categories by amplifying a deeper sense of "corporeal listening," which relates closely to the discussion of hermeneutics proposed by the German philosopher Hans-Georg Gadamer. Inciting a participation that awakens a "historical self-consciousness," each of these creations transcend formal aesthetic conventions that sought to minimize historical content in cultural productions after the Second World War. The works in question not only engage traumatic historical grounds but reveal how the past is only meaningfully engaged in our present interpretation of it [1].

Following Gadamer's discussion of the entwined relationship between poetry, history and culture, we will explore the way historical quotations emerge across poetry, artistic creation and architectural space. Understanding how the critical positioning, inherent absence, sophisticated tensions and pressures of Celan's poetry are transformed into Kiefer's paintings and Libeskind's museum, will demonstrate how these works provide vital sites of participation amid the fragmentation of traditional cosmological grounds at the heights of modernity. Presenting moments of disorientation, each creation reveals a poetic participation which transcends Cartesian dualities that became cauterized, after the atrocities of WWII, into the aesthetics of our modern world. To understand this participation we begin with each work in its context, and respond to what is given by the work, from the bottom-up. Here, we find creations that bridge over the aforementioned separations, revealing an empathetic and ethical overlapping between the outside and inside, the past and present, the self and the Other [2].

\section{Paul Celan and Todesfuge}

The poet Paul Celan, was born Paul Antschel in 1920, to German speaking Jewish parents in Czernowitz, Bukovina, on the eastern outpost of the Austrian Empire. His early years were steeped in the songs and folktales of German culture, which included the poems of Goethe and Höderlin, the writings of Schiller, and the music of Bach. From an early age, Celan spent his time reading the poetry of Rainer Maria Rilke as well as translating works of Verlaine and Shakespeare from French, English, and Romanian, into German. Testi- 
mony to the importance of his poetry has been discussed by Nobel laureates and the philosophers Martin Heidegger, Theodore Adorno, and Hans-Georg Gadamer. George Steiner places his work at the "summit of German poetry" and he has been described as "one of the few modern poets in whom life and the work cleave so closely" [3].

The tragic event which most inspired the creation of Todesfuge, occurred in late June, 1942. On a rare evening he had spent away from home, Celan's parents were picked up in an overnight raid by the Nazis. Shortly thereafter, Celan was forced into a Romanian labour camp where he learned bit by bit the horrifying

\section{Todesfuge}

SCHWARZE Milch der Frühe wir trinken sie abends wir trinken sie mittags und morgens wir trinken sie nachts

wir trinken und trinken

wir schaufeln ein Grab in den Lüften da liegt man nicht eng

Ein Mann wohnt im Haus der spielt mit den Schlangen der schriebt

der schriebt wenn es dunkelt nach Deutschland dein goldenes Haar Margarete

er schreibt es und tritt vor das Haus und es blitzen die Sterne er pfeit seine Rüden herbei

er pfeift seine Juden hervor lässt schaufeln ein Grab in der Erde

er befiehlt uns spielt auf nun zum Tanz

Schwarze Milch ser Frühe wir trinken dich nachts wir tinken dich morgens und mittags wir trinken dich abends

wir trinken und trinken

Ein Mann wohnt im Haus der spielt mit den Schlangen der schreibt

der schreibt wenn es dunkelt nach Deutschland dein goldenes Haar Margarete

Dien aschenes Haar Sulamith wir schaufeln ein Grab in den Lüften da liegt man nicht eng

Er ruft stecht tiefer Erdreich ihr einen ihr andern singet und spielt

er greift nach dem Eisen im Gurt er schwingts seine Augen sind blau

stecht tiefer die Spaten ihr einen ihr andern spielt weiter zum Tanz auf

Schwarze Milch der Frühe wir trinken dich nachts

Wir tirinken dich mittags und morgen wir trinken dich abends

wir trinken und trinken

ein Mann wohnt im Haus dien goldenes Haar Margarete news that his parents had perished. John Felstiner emphasizes how these dreadful events influenced the "unimaginable loss that grounds all of his writing" [4]. Never receding, the despair and tragedy of this period likely aggravated severe bouts of mental instability, which eventually led Celan to his suicide when he lowered himself into the Seine River in April of 1970.

Originally written in Romanian in 1944 and put in its final form in 1945, Todesfuge was translated into German in 1948. It is a stirring artistic piece and one of the most translated poems of the twentieth century. The poem reads:

\section{Death Fugue}

BLACK milk of daybreak we drink it at evening we drink it midday and morning we drink it at night

we drink and we drink

we shovel a grave in the air where you won't lie too cramped

A man lives in the house he plays with his vipers he writes

he writes when it grows dark to Deutschland your golden hair Margarete

he writes it and steps out of doors and the stars are all sparkling he whistles his hounds to stay close

he whistles his Jews into rows has them shovel a grave in the ground

he commands us play up for the dance

Black milk of daybreak we drink you at night

we drink you at morning and midday we drink you at evening

we drink and we drink

A man lives in the house he plays with his vipers he writes

he writes when it grows dark to Deutschland your golden hair Margarete

Your ashen hair Sulamith we shovel a grave in the air where you won't lie too cramped

He shouts dig this earth deeper you lot there you others sing up and play

he grabs for the rod in his belt he swings it his eyes are so blue

stick your spades deeper you lot there you others play up for the dance

Black milk of daybreak we drink you at night we drink you at midday and morning we drink you at evening

we drink and we drink

a man lives in the house your goldenes Haar Margarete 
dein aschenes Haar Sulamith er spielt mit den Schlangen

Er ruft spielt süsser den Tod ist ein Meister aus Deutschland

er ruft streicht dunkler die Geigen dann steigt ihr als Rauch in die Luft

dann habt ihr ein Grab in den Wolken da liegt man nicht eng

Schwarze Milch der Frühe wir tinken dich nachts wir trinken dich mittags der Tod is ein Meister aus Deutschland

wir trinken dich abends und morgens wir trinken und trinken

der Tod is ein Meister aus Deutschland sein Auge ist blau

er trifft dich mit bleierner Kugel er trifft dich genau

ein Mann woht im Haus dein goldenes Haar Margarete

er hetzt seine Rüden auf uns er schenkt uns ein Grab in der Luft

er spielt mit den Schlangen und träumet der Tod ist ein Meister aus Deutschland

dien goldenes Haar Margarete

dien aschenes Haar Sulamith

\subsection{Brief Analysis of the Poem}

Given in changing tenses, the poem narrates a point of view from within a Nazi camp, where Jewish prisoners are tyrannized by a camp commandant [5]. Identification with these events is opened through a broken semantic arising from the poem's sudden breaks and pauses and in fissures between strange couplets, such as: black-and-milk, graves-and-sky, Jews-and-hounds, and between the names of two women, Margarete and Sulamith. Margarete is the one to whom the German guard writes love letters and whose golden hair evokes her Aryan identity. By contrast, Sulamith is the Jewish woman, whose hair is "ashen from burning" [6]. Participation with these dreadful events is conjured through the constant changes between the first and thirdperson, adding to a cadence of fragmentation that stretches out over the poem.

In his analysis of Celan's poetry, Hans-Georg Gadamer discusses how unlike prosaic language, which transports meaning in a familiar coherence, the splintered language of the poem presents potential meanings which seem to be "wedged together" [7]. your ashenes hair Sulamith he plays with his vipers

He shouts play more sweetly this Death is a Master from Deutschland

he shouts scrape your strings darker you'll rise up as smoke to the sky

you'll then have a grave in the clouds where you won't lie too cramped

Black milk of daybreak we drink you at night

We drink you at midday Death is a master aus Deutschland

we drink you at evening and morning we drink and we drink

this Death is ein Meister aus Deutschland his eye it is blue

he shoots you with shot made of lead shoots you level and true

a man lives in the house your goldenes Haar Margarete

he looses his hounds on us grant us a grave in the air

he plays with his vipers and daydreams der Tod ist ein Meister aus Deutschland

dein goldenes Haar Margarete

dein aschenes Haar Sulamith

Sentences like, "Speilt süsser den Tod der Tod ist ein Meister aus Deutschland," places the word "Tod" twice, and closely together, so that it grinds up against itself, "making death the subject of mastery" and "both outcome and origin" [8]. In other places, the "broken language" of the poem extends outwards towards the invisible, towards silence, inciting a form of empathic identification with tragic historical events [9]. Not capable of fully grasping this situation we are left with a lingering and ethereal presence.

Gadamer explains how the poem, like all language, always implies something else, stating, "Like any word in a conversation, the poem also has the character of a rejoinder [Gegenwort], which makes audible what is in fact not said, but rather presupposed as an expectation of meaning" [10]. Through disjuncture, Todesfuge presents us with the open ends of stories into which the memory slips and our own involvement begins. For these reasons Gadamer discusses Celan's poetry as a "living language," one which is layered with references and iterations which not only emerge from its being read, but from its being spoken. "Only when the wind of your language rushes in with radiating purity does the 
path to the poem begin," states, Gadamer. This spoken engagement instigates a reversal of roles between the self and the other, between the "I" and "we" essential to the translation bred into the poem itself.

During Celan's 1958 acceptance speech for awards honoring his contribution to poetry, he clarified this participation when he referred to his poetry as Flaschenpost or "a message in a bottle, something always on its way to someone-both an invitation and a provocation" [11]. Celan states, "I see no essential difference between a poem and a handshake...a poem can be a message in a bottle...a making towards something...perhaps towards an addressable Thou...the poem wants to reach the Other, it needs this Other, it needs an Over-Against" [12]. During his later Meridian Speech, given on occasion of receiving the Georg Büchner Prize in Darmstadt, Germany, on October 22, 1960, he spoke of Atemwende or Breath-turn, which describes the ability of poetry to weaken the division between inside and outside, between the self and the Other. Gadamer clarifies this involvement when he states:

It is futile to differentiate between me and you, between the "I" and the poet and all of us whom the poem reaches. The poem says to the poet, as well as to all of us, that stillness is welcome. It is the same stillness heard in the turn of a breath, the ever so quiet recurrence of the act of breathing. More than anything, this is the 'breath-turn,' the sensuous experience of the silent, calm moment between inhaling and exhaling... this instant when breath returns is the subdued hope bound up with every return [Umkehr] to resonate [13]

\section{Contemporary Translations of Todesfuge}

It was the generation of artists following Celan who were responsible for invigorating the participation that Todesfuge had initiated and reinterpretations of the poem by Anselm Kiefer and Daniel Libeskind were foremost in rescuing Todesfuge from popularization. The commercialization of the poem had become a concern for Celan who feared that the oversimplification of Todesfuge had replaced its task as "a sustained work of memory" as well as its ability to evoke a genuine engagement with the past [14]. This occurred during trends towards formalism which had increased in the arts exponentially in the 1950 's. Being suspicious of the historical tradition tainted by the National Socialist appropriation of themes, artists and critics alike, began to favor a "non-historical," abstract and formalist approach to cultural productions, since this avoided historical reference in its prohibition of direct content. In this context much of the contemporary readings of
Todesfuge favored only the euphony of the poem, which Celan believed avoided a genuine engagement with remembrance.

3.1. Anselm Kiefer's Paintings: Nuremburg and Shulamith. In the early 1980's, a symbiotic relationship between Todesfuge and Anselm Kiefer's paintings emerged, leading to a major transition in the subject matter of the artist's work. Reluctant to discuss the details of his life and working methods, Kiefer has released only one autobiographical document in 1977 as an accompaniment to the exhibition Kunstverein in Bonn. The last lines of the document read, "The essential is not yet done," marking a change of direction away from understanding the artist's German heritage to a focus on the victims of historical progression [15]. From 1980 forward, Kiefer began translating the aural poetics of Todesfuge into the plasticity of his paintings, giving figuration to all that had been repressed in the vacuum of post-war Germany [16].

Most ostensibly, Kiefer's painting Nuremberg (1982) (Figure 1) transposes the lines "your golden hair Margarete" into a mixture of acrylic, emulsion and straw. Here, straw becomes both symbolic of the German landscape and straw-blond hair of an idealized Germanic beauty [17]. Cut off from the soil and strewn in the air, it evokes the sense of amputation, turmoil and anxiety. Just as Celan's poem incites a certain "listening to language" through disjuncture, Kiefer pulls the viewer into the depiction of a landscape only to undo perspectival space, giving multivalent amalgamations of text, image and materiality, which confront us with unnerving historical reference.

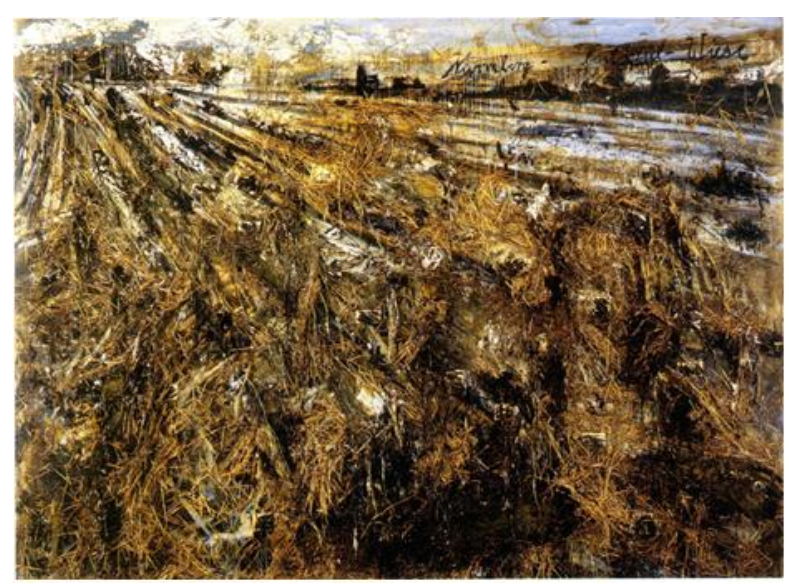

Figure 1. Anselm Kiefer's Nuremberg, 1982. Acrylic, emulsion and straw on canvas 110" x 149" Collection of Eli and Edythe L. Broad, Los Angeles. 


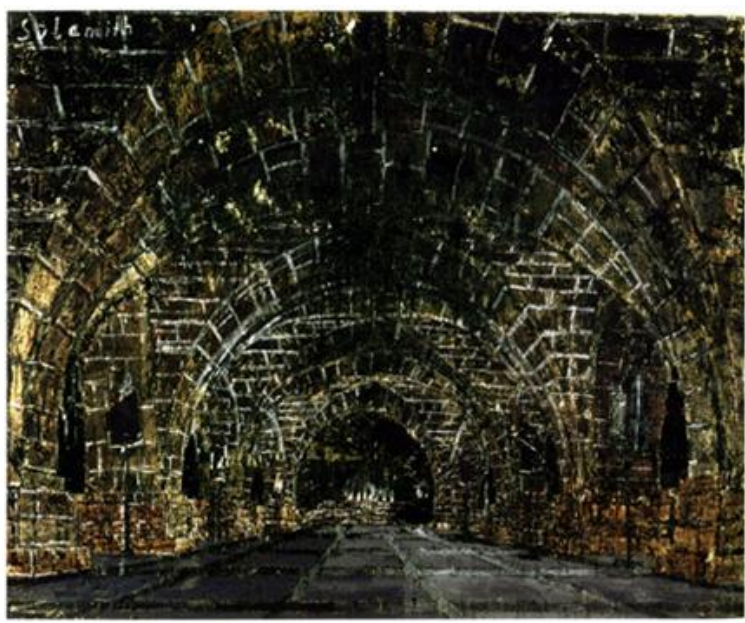

Figure 2. Anselm Kiefer's Sulamith, 1983. Oil, acrylic, emulsion, shellac, and straw on canvas, 114" x 145" Saatchi Collection, London.

In Sulamith (1983) (Figure 2), the presence of the Nazi culprit in Celan's poem appears equally as the looming presence of Nazi architecture. By combining references from Todesfuge with The Berlin Hall of Soldiers by Wilhem Kreis, Kiefer transforms what was used as an architectural symbol of the erasure of the Jewish culture by National Socialists into a memorial for the Jews in the space of the painting. Following the lines "Black Milk of Daybreak," Kiefer restructures the architecture, collapsing building into oven. The perpetual night of the poem is present in an atmosphere of darkness and soot, under layers of oil, ash, straw, and wood. In his book, Sites of the Uncanny: Paul Celan, Specularity and the Visual Arts, Eric Kligerman discusses how Kiefer's work consists "of combinations of distinct forms of representation: architecture, the photograph of Kreis's design, poetic inscription, and painting itself" [18]. This sedimentation of media is inherently tied to the overlapping of historical themes that leads the viewer into the recesses of traumatic memory.

These mixtures, along with the considerable scale of both paintings, immediately place the observer in the role of the historical subject [19]. Andrea Lauterwein suggests that the lack of figural representation in these paintings allows us to recognize that "humans are only present in these examples through manifestations of cultural memory, through their works and their acts of destruction" [20]. Since the cues given within these paintings reverberate beyond direct images of death, they help to make visible that which is not seen [21]. The uninhabited landscape in Nuremburg or the name Sulamith, a whisper in the upper left had corner of the painting, resonate with the last word of Celan's poem. Not bounded by punctuation, these last lines are said to "remain in suspense", extending the music of the poem out over a void and towards silence [22]. Likewise, the sense of erasure within Kiefer's canvasses places us in a situation where we are forced to confront a tragic past.

3.2. Daniel Libeskind's Jewish Museum, Berlin. The Jewish Museum, Berlin, by Daniel Libeskind invites a similar involvement with traumatic historical grounds. Completed in 2001, Libeskind has described the design as a site for the city's "historical self-understanding" and as an address to the "entwined relationships between the figures of the Germans and the figures of the Jews" [23]. Like Celan, Libeskind also felt a deep connection to the project from its inception, stating, "I felt this was not a program I had to invent, but one in which I was implicated from the beginning, having been born only a few hundred kilometers away in Lodz, Poland, I lost most of my family in the Holocaust" [24]. Of the 165 designs submitted from around the world, Libeskind's proposal was awarded first-prize and became the first of the architect's commissions to symbolize Judeo-German relations on a world scale.

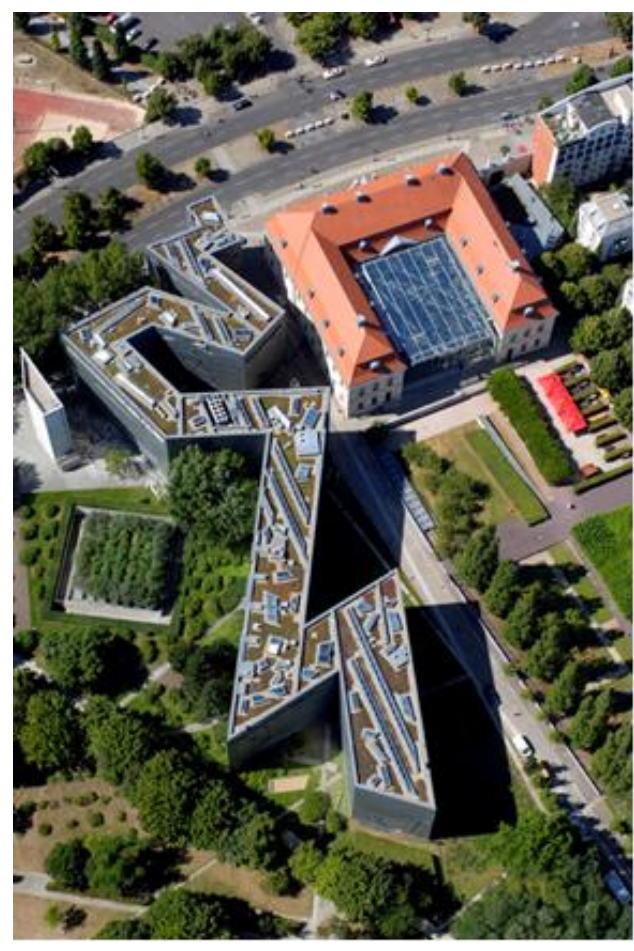

Figure 3. Aerial view of the Jewish Museum, Berlin. (Image from Studio Daniel Libeskind)

(http://www10.aeccafe.com/blogs/arch-

showcase/2012/04/27/jewish-museum-berlin-in-germany-bystudio-daniel-libeskind/) 


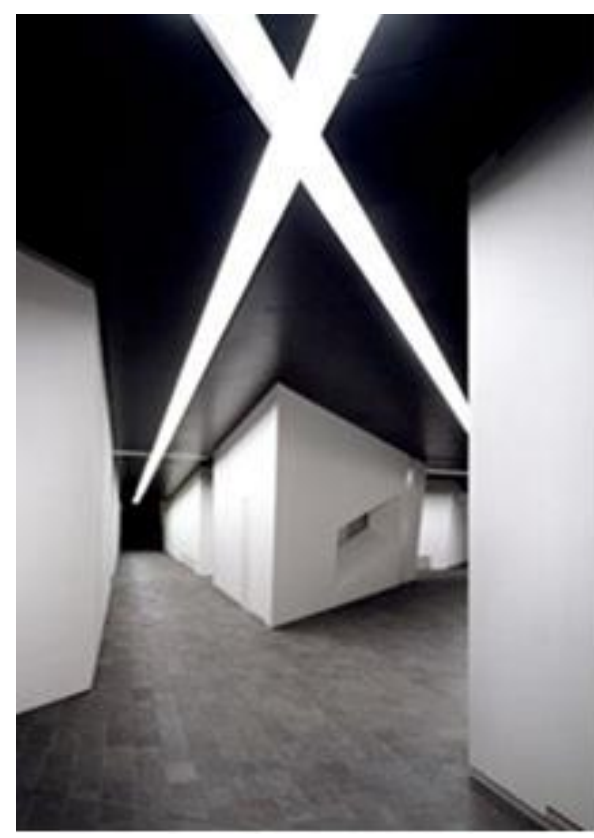

Figure 4. Interior pathways of the Jewish Museum, Berlin. (Image from Studio Daniel Libeskind, see Fig.3 for the link)

From an aerial view (Figure 3), the overall design resembles a disjointed Star of David. From the ground, it is experienced as a series of pathways (Figure 4), which move through fragments and displacements, organized around "one a straight line, broken into many fragments, and the other a tortuous line, continuing indefinitely" [25]. In the same manner as Todesfuge and Kiefer's paintings, the museum functions as an instrument that invites one to see through history-a building that is not a representation of culture and art, but one which the architect describes as "a mechanism to interpret them, by walking through it, by looking out of windows, by opening doors, by traversing space" [26].

Descending into the halls of the museum a strange sense of disorientation diminishes our ability to locate ourselves. The carved windows, narrowing, slanted and meandering halls, undermine expectations typically produced by museum interiors so that "a casual walk through the museum becomes something perceptually and spatially disorienting" [27]. Just as the lines of Celan's poem stumble along through missteps, fissures and breaks towards silence; the halls of the museum eventuate upon six voids that cut into the paths of the museum (Figure 5). Remaining purposely unfilled, these voids emphasize what Libeskind describes as an "invisible matrix of connections" where the "readervisitor encounters the historical rupture of the holocaust" [28]. By putting "absence on display" these destabilizations obfuscate our objective understanding of historical progression, alluding to all that has been lost. Like Todesfuge, these voids reveal places of "terrifying silence" [29].

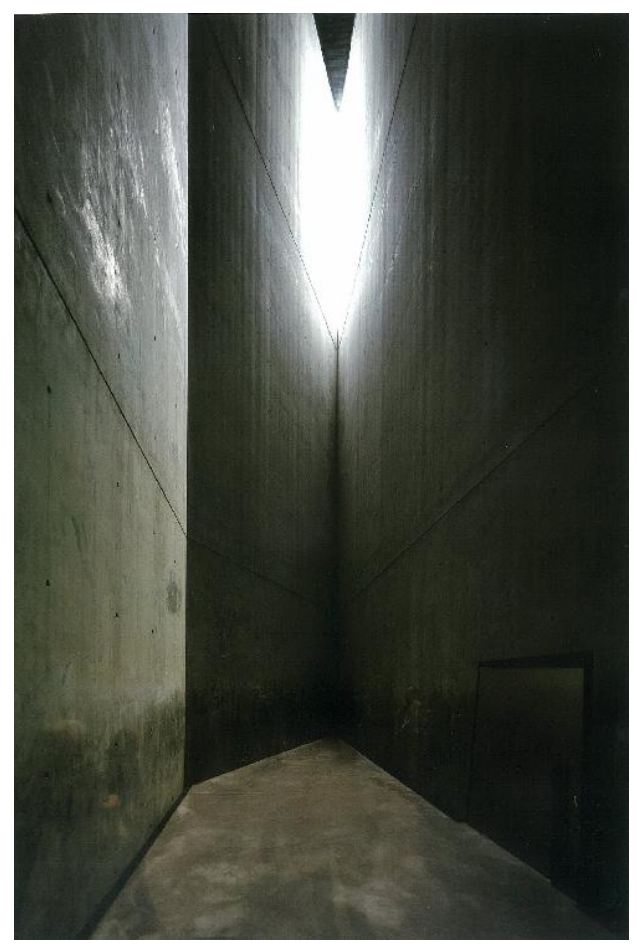

Figure 5. Interior Void of Daniel Libeskind's Jewish Museum, Berlin. (Image from Studio Daniel Libeskind, see Fig. 3 for the link)

Through translation, both Kiefer and Libeskind take Todesfuge through a cycle of complex transformations, which see Celan's poetics transmuted into the combinations of imagery, materiality, and space. Like the Breathturn of Celan's poem opened between word fragments, these works make recognizable that which is already at work in natural vision - the coalescence of memory and imagination and the awareness of profound historical grounds.

\section{Criticality, Metonyms, and the Historical Trace}

Most essential to the relationship between poem, paintings and architectural space is recognizing how a historical consciousness emerges as we sink more deeply into correlations that echo with religious and mythical quotation. For instance, John Felstiner clarifies how the impact of the first line of Todesfuge, "BLACK milk of daybreak," not only situates us within the Nazi camp but echoes with the story of creation given in the first lines of the Bible. Turning all days to black, the 
phrase presents a reversal of things that abolish essential nourishment. The inversion of day and darkness and black and milk, helps to evoke the unthinkable environment of the concentration camp, as well as intonate the perversion of Jewish religious traditions in Nazi ideology. In this way, these powerful reversals demonstrate how, as Felstiner suggests, the surreal and the tragic had overtaken reality in Nazi-ridden Europe.

In a similar way, references to music in Todesfuge, either in the cadence of the spoken poem or in phrases such as "play more sweetly this Death is a Master from Deutschland," are inevitably perceived against the backdrop of music and death that is deeply woven into German culture. Popular nursery rhymes such as Cockchafer Fly (Maikâfer flieg) relate directly to the tragedies of The Thirty Years War; and works like Wagner's “Liebestod," Mahler's Kindertotenlieder, and the "Art of Fugue" by Johann Sebastian Bach, were "all picked up by the Nazi's to signify the genius of the race....and used as a symbol for hostile territorial expansion" [30]. Felstiner argues that Celan's involvement with these leitmotifs was a search for his own standpoint from within a compromised tradition, one which sought to demonstrate the changes that music and culture had undergone since Wagner [31].

Kiefer also begins from within the German Romanic Tradition in order to subvert references that had been appropriated by the Nazis. To involve the spectator with this critique, his work contains a fundamental joining together of multiple ideas and expressions spanning the spectrums of historical, mystical and philosophical reference. For example, by using particular names and places that refer directly to imagery the Nazis had appropriated, Kiefer activates the earlier power of myth to evoke a critical positioning. Prodigious references to Nazi architecture placed alongside fragments such as hair, ash and railroad tracks in other works, open what Andrea Lauterwein describes as a "mnemonic archive of the public domain," which invites us to see anew the sites of destruction that have been repressed in contemporary European culture.

Engaging with historical introspection, Kiefer's work also reveals two parallel uses of mythical reference that had emerged during Romanticism. First, it displays the innocence and the folkloristic value of myth that was appropriated and perverted by the Nazis. Yet in a more critical manner, his work displays the universal power of myth, through the working out of parallels in which the past and the present interpenetrate. Armin Zweite clarifies Kiefer's use of mythical quotation, stating: "This is not simply a matter of rehabilitating what has been repressed and forgotten, or of finding the future foreshadowed in the past; it is an intuitive process, which traces the external forms of ancient legends back to a nucleus of constants which the artist would certainly never think of categorizing as eternal certainties." Zweite maintains that to the contrary, Kiefer's work refers to "eternal uncertainties, or permanently open questions," and in so doing, reveals the innate power of myth, its mysterious evocations and interpretive power [32].

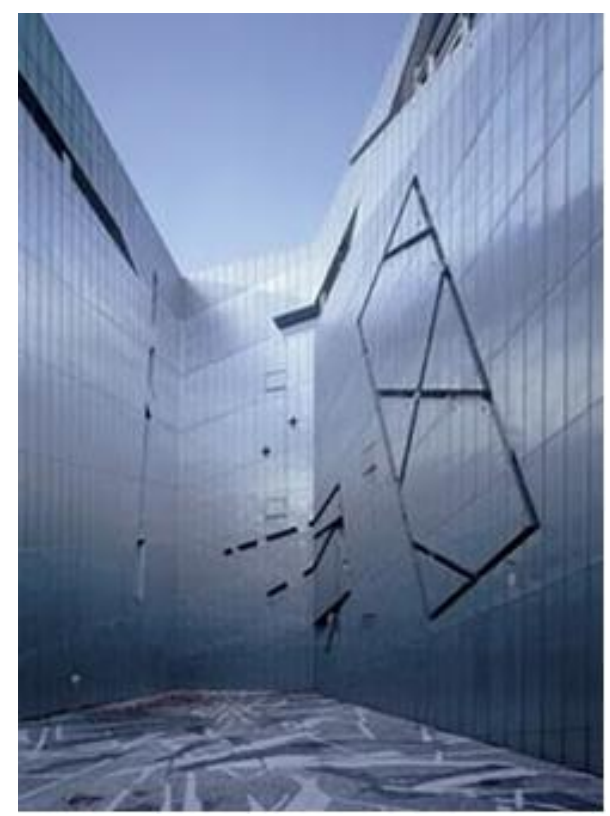

Figure 6. The Paul Celan Court of Daniel Libeskind's Jewish Museum, Berlin. (Image from the internet [18])

Libeskind's design awakens a similar critical positioning in the Paul Celan Court (Figure 6) which exists between the Holocaust Tower and the E. T. A. Hoffmann Garden (Garden of Exile and Emigration). Here, we encounter an alcove that memorializes the events of Kirstallnacht (The Night of Broken Glass), which occurred on November 9-10, 1938. On the ground of the court, Libeskind integrates shard-like inlays that resemble the broken glass that lay across the streets of Berlin after the Nazis had ransacked Jewish stores and homes. Following etchings produced by Celan's Widow, Giséle Celan-Lestrange, the angular fragments appear to have fallen onto the ground of the courtyard from punctures in the building. By transforming this debris into stone, Libeskind memorializes an event which has been seen as the beginning of further political persecutions of the Jews that eventuated in the Final Solution and then the Holocaust.

Other metonymic fragments in both Kiefer's paintings and Libeskind's museum also perpetuate a 
historical awareness in the experience of their works. For example, Lauterwein points out how the straw in Margarete, combined with the word "Nuremburg," written onto the surface of the painting adhere material to place, creating a loaded symbolic field, since Nuremburg has long been considered the ideological center of Nazi idealism. No longer a vital or renewable resource, straw becomes symbolic of a subservient "weak-willed collectivity," states Lauterwein [33]. The physical fragility of the material, evocative of both growth and decay, is bound to deteriorate, implying a convergence of historical progression and the fate of Germany following its championing of Nazi idealism.

Similarly, the cultural artefacts displayed throughout Libeskind's museum help to accentuate the cavernous voids of the design, offsetting historical reminders. Remnants, of surviving religious objects or artifacts used in the day to day life of Jewish citizens serve as metonymic reminders of the people that had once used them in Jewish rituals. The most astounding example is the Gedenkbuck, a manuscript that includes all the names, dates and places of death of Europe's Jewish communities. By placing artefacts such as these up against the voids of the museum, they function as language does in Celan's poem, signalling an awareness of entire cultural grounds formed in juxtaposition with absence [34].

4.1. The Toponyms Margarete and Shulamith. The widest of voids and the most distinct threshold into historical reference initiated by Todesfuge is the relationship between Sulamith and Margarete. The interplay and tensions between these names reveal a genealogical pairing that traces a profound path through history. Traditionally, Shulamith has been known as the "black and comely" princess in the Song of Songs (Song of Solomon) in the Bible, whose name holds echoes of the Hebrew words "shalom" for peace and "Yerushalayim" for Jerusalem. John Felstiner reminds us that being written 'Shulamitte' in the Bible, the word is often seen as the Jewish people itself [35]. In contrast, Margarete evokes the fair haired Gretchen of Goethe's Faust who became a model for all women in the Germanic culture.

Following from Todesfuge, Kiefer maintains a separation between these German and Jewish symbols, which never appear on the same line of the poem, and are never represented beside one another in his paintings. Lauterwein points out how the relationship between Margarete and Shulamith can only be read across the breadth of Kiefer's work; and unlike Shulamith, whom is given a figural presence in several paintings, Margarete never appears as a figural embodiment but always remains an abstract idealization
[36]. In these cross-references, it is possible to see the ash and shadow that exist in or behind the depictions of straw and mixed within the paint of Kiefer's landscapes as implying the absence of Margarete's Jewish counterpart, since charcoal and black paint are both themselves derived from burning. In Kiefer's view, Germany vandalized itself and its civilization by destroying its Jewish participants and by frequently alluding to both figures, many scholars see this as his attempt to make Germany whole again [37].

Eric Kligerman suggests a similar relationship between German and Jewish reference in proximities of the new addition of the Jewish Museum and the Baroque Kollegienhaus on Lindenstrasse. Originally commissioned by Friedrich Wilhelm I as the first Prussian Court of Justice, the Stadtmuseum was constructed in 1735 in the old city center and exists as a clear symbol of distinctly Germanic tradition. In the design of the Jewish addition, Libeskind is careful that the only bridging between these buildings occurs through the proximity of views and the shared entrance to both museums. By emphasising the autonomy of each structure as well as their inevitable proximity to one another, critics like Kligerman, and Libeskind himself, propose that the design seeks to unite the cultures "without suggesting a seamless rapprochement" [38].

However, the relationships stemming from the typographical parings presented in the abovementioned works demonstrate important distinctions between the creations of Celan and Kiefer, and that of Libeskind's museum. The sophisticated tensions established between the two women throughout Celan's poem and in the mixtures of ash and straw in Kiefer's paintings reveal a symbolic resonance that is felt at an essential level. The ironic alterations brought forward through the pressures of the spoken poem resound with the interplay of ash and straw in Kiefer's paintings, both symbolizing the excruciating and complex relationships between Jewish and German cultures. Furthermore, just as the words Shulamith and Margarete intonate religious associations into the context to which the poem refers, the combinations of material in Kiefer's paintings resonate with mythical connections that merge with the themes of his work. For example, the straw, strewn across the surface of Nuremburg, suggests a relationship to Ceres, the Roman goddess of the cycles of growth and guardian of underworld portals, who, being the divinity of the harvest, was symbolized by straw, grain, poppies or wheat crowns. Official harvest festivals in tribute to Ceres allowed spirits of the dead to emerge from below and roam among the living [39]. In the context of Kiefer's work, the relationship of death, resurrection, and the expiation that is present in his dealings with a 
tragic past, allows these chronologically disparate themes to emerge by using the properties of straw itself. In Libeskind's design, however, the difficult relationship between the Germans and Jews, being left to mere contiguity are not explored with the same symbolic overlays felt in the substance of Kiefer's work or the vociferation of Celan's poem.

\section{Conclusion: Sites of Participation and Poetic Entwining}

Yet, common to the work of Celan, Kiefer and Libeskind is the way each creation involves us with what Gadamer describes as the "working and unworking of the work." By subverting the way the spectator is accustomed to relating to historical images, each work incites a "perceptual dislocation," which "shatters" such distinctions as the self/Other and interior/exterior [40]. Where the attendee of the work expects to see objects that engage direct historical depictions, the poet, artist and architect withhold any act of voyeurism by displacing these expectations giving only a departure towards this Other. Kligerman suggests that just as Celan's poem acknowledges the desire for an empathetic identification with dreadful historical events, Todesfuge acknowledges the very impossibility of sustaining such identification. Kligerman states, "There is no catharsis or purgation given...what exists in Celan's poem is a series of perceptual wounding's, which cannot be integrated into any redemptive narrative about the Holocaust" [41].

Kligerman further argues how the participation evoked by Celan's poem occurs with an effect akin to the layering of Cubist compositions, "which always try to discern things from numerous angles [Sichtwinkeln]...through various breaks and divisions" [42]. Unable to reveal fully the thing being observed, poet and artist alike only portray the object in pieces. To a similar extent, Celan himself states of his work: "I strive to reproduce at least linguistically, sections from this spectral analysis of things, to make them visible simultaneously in various aspects and in permeations with other things that are related, subordinate, or contrary. For, unfortunately, I cannot make things completely visible" [43]. Through our own involvement with the many angles opened by the work, a unity of meaning prevails from within its fissures and tensions, splits and cracks.

In the essay "Who am I and Who are You" Gadamer summarizes this participation, suggesting that what is present in the verses of Celan's poetry is an "interplay between the I and you that promises a catch," an involvement that moves beyond standard information given by specialists and objective historical analysis
[44]. Correspondingly, just as the 'I,' 'you,' and 'we' are pronounced in an utterly direct, yet continually shifting manner in Todesfuge, the waywardness of Kiefer's paintings and the voids of Libeskind's architecture imparts a duty of translation onto the attendee, which attests to the preservation of an underlying alterity in the work itself. "The Other" who is foreign and irrecoverable in the work, compels the reader to recall through its traces what remains lost and disseminated throughout the creation [45].

Thus, verse, material, or space, is no longer an "object for me" but rather exist as an event of "selfpresentation" that invites us into its "open-ended activity" or energeia, Gadamer elucidates:

Of course we position ourselves outside of the work yet we cannot close the work or we miss it... One can only really complete a song by joining in. It is necessary to complete and to understand what the poem wants to say. Such a meaning is not the goal of an abstract totality, but the unalterable demand that anything written make sense...In the here and now of the poem-and the poem has only this one, unique, momentary present-even in this immediacy and nearness the work issues a challenge and requires an answer...the participant must belong to the play [46]

In his Truth and Method, Gadamer describes how the limits of the poetic creation makes room for an "excess" or "play", which always appears as a "self-movement." He describes this as the "intimacy of the event" in which we are turned "inside out" in front of the work, "an activity whereby we make the thing our own even while remaining a stranger to it." Through this engagement the work never speaks to a disengaged subject but rather "intercepts us, situating us in a space of open indeterminacy where the rule of identity and the legislation of concepts are no longer in control" [47].

Statements like these remind us that written poetry itself, while made of language, is not the mundane use of it. Gadamer suggests that poetry is not like the prosaic everyday language of concepts and intentional fulfillments, stating: "In poetry, language is no longer a form of mediation" [48]. While "language bound [sprachgebuden]," poetry works in contrast to what language has become in our fully modernized culture. Instead of being applied to the world, the poetic creation evokes a "listening to," and "remembrance of language," which hasn't been tuned out, repressed or forgotten. The same is true of Kiefer and Libeskind's work, which always "interrupts our attempts to reduce it" [49], inducing openness to the strangeness or Otherness of things, materiality and space. 
This participation reveals the greatest intersection of these works to be their ability to amplify an essential interplay between the visible and the invisible. In the book The Crossing of the Visible, author Jean-Luc Marion suggests, "that the painter, like the alchemist, makes visible what without him would have remained definitively invisible" [50]. Likewise, each of the aforementioned creations demonstrates how poet, artist or architect gives to be seen what would otherwise remain without him forever banished from the perceptible and lost in the accelerated forgetting of modern cultural progression. By foregrounding the essential task of poetry to point beyond itself to the Other, the poetic artefact insures the opening up of the world to time and history [51].

In recognizing these connections, the distinctions between art, architecture, and poetry begin to blur; since in each case, the work amplifies an intertwining between memory and imagination that underlies our ubiquitous experience of the world. Celan, Kiefer, and Libeskind each depend upon the synchronous qualities of their work which allow the past and present, the tragic and the hopeful, the particular and the universal to be recognized through the experience of the work. Quoting the American poet Charles Berstein's ars poetica, Gadamer elucidates the fundamental relationship of spoken poetry as "the flesh and breath of language," which summarizes well the engagement provoked by all of these creations. Gadamer states:

The intersection of absorption and impermeability is precisely, flesh, as Merleau-Ponty uses this term to designate the intersection between the visible and invisible. This is the philosophical interior of my inquiry. The thickness of words ensures that whatever of their physicality is erased, or engulfed, in the process of semantic projection, a residue tenaciously inheres that will not be sublimated away...The thickness of writing between the reader and the poem is constitutive for the poem of its visibility and for the reader of the outer limit of his or her absorption in the poem; it is not an obstacle between them, it is their means of communication. Like the thickness of writing, far from rivaling that of the world, is on the contrary the sole means it has to go to the heart of things by making itself part of the material world, absorbed by it [52]

Just as the spoken word allows us to find the germ of universality, which enables us to understand our world and each other, our encounter with the poetic creation allows both thinking and feeling, inside and outside, to merge [53]. In this activity we not only encounter ourselves, our questions and our own knowledge of the world, but we do so within a social space of recuperation that promises the possibility of reorientation. Since the aforementioned examples of poetry, painting or architecture each embed material from the world into the creation they become cultural instruments which allow us to consider anew our own conception of history. In these moments, history itself has no closure, since it is revisited, remembered, and in the case of these works, mourned-in the essential activity of translation. This hermeneutic involvement is not only essential to Celan's transformation of tragic historical grounds into poetry, or to the (re)incarnations of Celan's work, but makes recognizable the participation necessary for any ethical interaction - the vital entwining-between ourselves, the Other, and the world.

\section{References}

[1] Gadamer, H. G., The Relevance of the Beautiful, Cambridge, Cambridge University Press, 1986, 29.

[2] Dastur, F., World, Flesh, Vision. In: F. Evans and L. Lawlor, eds., Chiasms: Merleau-Ponty's Notion of Flesh, New York, State University of New York Press, 2000, 41.

[3] Felstiner, J., Selected Poems and Prose of Paul Celan, New York, Norton \& Company, Inc., 2001, xxiii.

[4] Ibid., xxi.

[5] Ibid., 35.

[6] Rosenthal, M., Anselm Kiefer, Illinois, The Art Institution of Chicago/Philadelphia Museum of Art, 1987, 96.

[7] Ibid., p.13.

[8] Felstiner, J., Paul Celan: Poet, Survivor, Jew, New Haven, Yale University Press, 1995, 39.

[9,] Kligerman, E., Sites of the Uncanny: Paul Celan, Specularity and the Visual Arts, Berlin, Walter de Gruyter GmbH \& Co, 2007, 111.

[10] Krajewski, B., trans. Gadamer on Celan: Who Am I and Who Are You? And Other Essays, Albany, State University of New York Press, 1997, 131.

[11] Kligerman, E., Sites of the Uncanny: Paul Celan, Specularity and the Visual Arts, Berlin: Walter de Gruyter GmbH \& Co, 2007, 17 - 18.

[12] Felstiner, J., Paul Celan: Poet, Survivor, Jew, New Haven, Yale University Press, 1995, xxxii.

[13] Krajewski, B., trans. Gadamer on Celan: Who Am I and Who Are You? And Other Essays, Albany, State University of New York Press, 1997, 73. 
[14] Kligerman, E., Sites of the Uncanny: Paul Celan, Specularity and the Visual Arts, Berlin, Walter de Gruyter GmbH \& Co, 2007, 20

[15] Rosenthal, M., Anselm Kiefer, Illinois, The Art Institution of Chicago/Philadelphia Museum of Art, 1987, 11.

[16] Kligerman, E., Sites of the Uncanny: Paul Celan, Specularity and the Visual Arts, Berlin, Walter de Gruyter GmbH \& Co, 2007, 196.

[17] Lauterwein, A., Ansem Kiefer/Paul Celan: Myth, Mourning and Memory, New York, Thames and Hudson, 2007, 91.

[18] Kligerman, E., Sites of the Uncanny: Paul Celan, Specularity and the Visual Arts, Berlin, Walter de Gruyter GmbH \& Co, 2007, 223.

[19] Lauterwein, A., Ansem Kiefer/Paul Celan: Myth, Mourning and Memory, New York, Thames and Hudson, 2007, 91.

[20] Ibid., 99.

[21] Kligerman, E., Sites of the Uncanny: Paul Celan, Specularity and the Visual Arts, Berlin, Walter de Gruyter GmbH \& Co, 2007, 21, 198.

[22] Lauterwein, A., Ansem Kiefer/Paul Celan: Myth, Mourning and Memory, New York, Thames and Hudson, 2007, 90.

[23] Libeskind, D., M. Schwarzer and J. E. Young, Daniel Libeskind and the Contemporary Jewish Museum: New Jewish Architecture from Berlin to San Francisco, New York, Rizzoli International Publications, Inc., 2008, 63.

[24] Ibid., 63.

[25] Ibid., 63.

[26] Ibid., 49, 63.

[27] Ibid., 63.

[28] Kligerman, E., Sites of the Uncanny: Paul Celan, Specularity and the Visual Arts, Berlin: Walter de Gruyter GmbH \& Co, 2007, 256.

[29] Ibid., 249.

[30] Felstiner, J., Selected Poems and Prose of Paul Celan, New York, Norton \& Company, Inc, 2001, p. 33.

[31] Ibid., 24.

[32] Zweite, A., The High Priestess, London, Abrams in association with Anthony d'Offay Gallery, 1989, 92.

[33] Lauterwein, A., Ansem Kiefer/Paul Celan: Myth, Mourning and Memory, New York, Thames and Hudson, 2007, 109.
[34] Kligerman, E., Sites of the Uncanny: Paul Celan, Specularity and the Visual Arts, Berlin, Walter de Gruyter GmbH \& Co, 2007, 251.

[35] Felstiner, J., Paul Celan: Poet, Survivor, Jew. New Haven: Yale University Press, 1995, 24.

[36] Ibid., 95.

[37] Lauterwein, A., Ansem Kiefer/Paul Celan: Myth, Mourning and Memory, New York, Thames and Hudson, 2007, 95.

[38] Libeskind, D., M. Schwarzer and James E. Young, Daniel Libeskind and the Contemporary Jewish Museum: New Jewish Architecture from Berlin to San Francisco, New York: Rizzoli International Publications, Inc., 2008, 63.

[39] Fowler, W., "Mundus Patet" in The Journal of Roman Studies, 2, 1912, 25-26.

[40] Kligerman, E., Sites of the Uncanny: Paul Celan, Specularity and the Visual Arts, Berlin, Walter de Gruyter GmbH \& Co, 2007, 24.

[41] Ibid., 27.

[42] Ibid., 152.

[43] Krajewski, B., trans. Gadamer on Celan: Who Am I and Who Are You? And Other Essays, Albany, State University of New York Press, 1997, 152.

[44] Ibid., $28-29$.

[45] Krajewski, B., trans. Gadamer on Celan: Who Am I and Who Are You? And Other Essays, Albany, State University of New York Press, 1997, 69.

[46] Ibid., 182.

[47] Ibid., 26.

[48] Bruns, G., Gadamer on Celan: Who Am I and Who Are You? And Other Essays translated by Bruce Krajewski intro by Gerald L.Burns, Albany, State University of New York Press, 1997, 6.

[49] Ibid., 6.

[50] Marion, J.L., The Crossing of the Visible, California: Stanford University Press, 2004, 11, 5.

[51] Krajewski, B., trans. Gadamer on Celan: Who Am I and Who Are You? And Other Essays, Albany: State University of New York Press, 1997, 12.

[52] Ibid., 45.

[53] Merleau-Ponty, M., "Phenomenology and the Sciences of Man" in The Primacy of Perception, USA, North Western University Press, 1964, 84. 